\title{
SURFACE ACTIVATION OF THE REINFORCING FILLER AND POLYMER MATRIX MODIFICATION AS EFFICIENT WAYS TO UPGRADE PROPERTIES OF POLYMER-MATRIX COMPOSITES BASED ON EPOXY MATRICES
}

\author{
${ }^{1}$ Engels Technological Institute (branch of SSTU) \\ Freedom square, 17, Engels, Russia \\ ${ }^{2}$ Yuri Gagarin State Technical University of Saratov (SGTU) \\ Politechnicheskaya street, 77, Saratov, Russia \\ ${ }^{3}$ Peoples' Friendship University of Russia \\ Miklukho-Maklaya Street, 6, Moscow, Russia \\ ${ }^{4}$ Moscow Automobile and Road Construction State Technical University (MADI) \\ Leningradsky Prospect, 64, Moscow, Russia \\ ${ }^{5}$ Saint Petersburg State University of Architecture and Civil Engineering \\ Vtoraja Krasnoarmejskaja ul., 4, St. Petersburg, 190005, Russia \\ 5 89312555919@mail.ru
}

Anton Mostovoy ${ }^{1}$, Sergey Arzamastcev², Yulia Kadykova², Igor Danilov ${ }^{3}$, Arthur Asoyan $^{4}$, Alexey Marusin $^{5}$

\begin{abstract}
The article is devoted to issues of interaction rise in the system "polymer matrix — reinforcing filler," which provides an increase in the complex of composite properties. Both surface activation of the reinforcing filler and polymer matrix modification are considered as options. It has been demonstrated that the number of functional groups available for interaction at the surface of basalt fibers increases due to desizing and surface activation of the fibers, which provides an increase in the complex of basalt fiber reinforced polymer properties.

It has been found that the use of different methods of surface activation allows providing high strength characteristics of carbon-, glass-, and basalt fiber reinforced polymers, exceeding similar characteristics of materials in which surface activation of the reinforcing filler was not performed. Experiments have proved that the use of unidirectional carbon fibers for reinforcement leads to a significant increase in the entire complex of mechanical properties, due to the possibility to realize stress-strain properties of the reinforcing filler to the limit.
\end{abstract}

\section{Keywords}

Reinforcement, basalt fiber reinforced polymer, carbon fiber reinforced plastic, surface activation.

\section{Introduction}

In recent decades, a substantial growth of the production of composite materials reinforced with chemical fibers has been observed. This is due to their high performance, low weight, and high corrosion resistance. The entirety of characteristics determines a vast scope of applications for such materials, starting from household application and ending with their use in the defense industry, aircraft and rocket production, and space industry, where a persistent struggle for weight reduction of structures exists (Barile et al., 2019).
Epoxy resins are the most common and universal of the whole family of resins, representing one of the best types of binding agents used in the production of fiberreinforced composite materials, due to a number of valuable properties: high dielectric index, mechanical strength, water resistance, low shrinkage during the transition to the cross-linked state, good adhesion to metals, porcelain, glass (Singla, Chawla, 2010).

The range of chemical fibers used for reinforcement has significantly narrowed for a number of reasons. Glass, basalt and carbon fibers are in most common use today 
Anton Mostovoy, Sergey Arzamastcev, Yulia Kadykova, Igor Danilov, Arthur Asoyan, Alexey Marusin — Pages 36-41

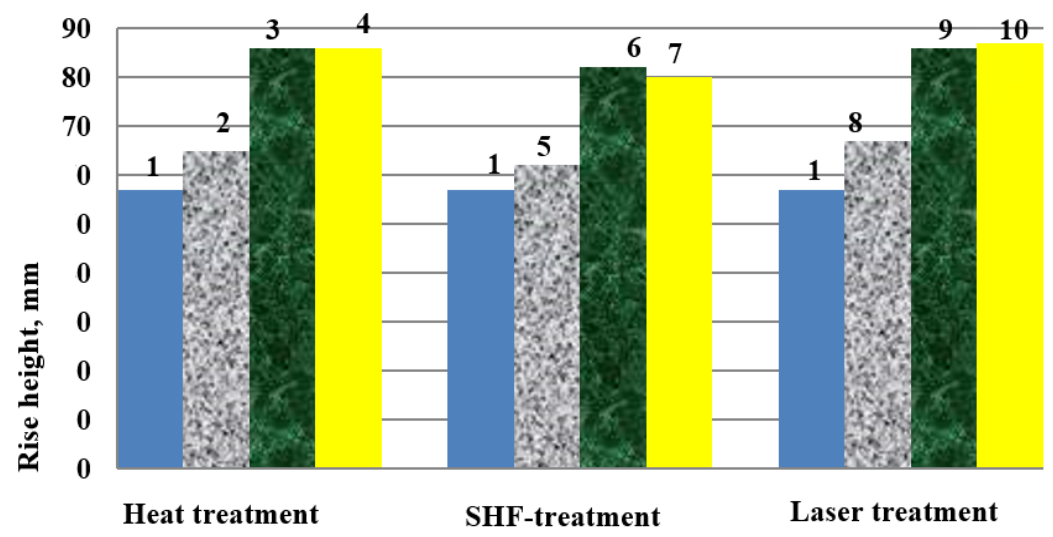

Figure 1. Change in wettability of basalt fibers with a mixture of monomers depending on the type of modification: 1 - untreated fiber; $2,3,4$ - heat-treated fiber at $200,250,300^{\circ} \mathrm{C}$, respectively; $5,6,7$ - SHF-treated fiber within $2,3,4$ minutes, respectively; 8,9 , 10 - laser-treated fiber within 1, 2, 3 seconds, respectively

(EL-Wazery, 2018; Matveeva, Lebedev, 2018; Gerasimova et al., 2018).

The important task of high-strength reinforced epoxy composites manufacture is to create conditions for chemical or physical-and-chemical interaction in the system "reinforcing filler - polymer matrix" (Colson et al., 2018).

This interaction is usually prevented by sizing and finishing agents applied to the fiber surface during its production. One way to increase the interaction force between the polymer matrix and the fiber is surface activation of the reinforcing fiber (Baloji Naik et al., 2014; Tijana et al., 2014; Molina, 2016).

\section{Subject, objectives, and methods}

The subject of the research was to increase interaction in the system "polymer matrix - reinforcing fiber." The objective of the research was to determine methods of surface activation of reinforcing fibers and polymer matrix modification in order to upgrade the complex of reinforced composites properties.

The epoxy resin ED-20, such hardening agents as polyethylene polyamine (PEPA) and PO-300, such plasticizing agents as trichloroethyl phosphate (TCEP) and tricresyl phosphate (TCP) were used as objects of the research.

The choice of TCEP and TCP is based on the presence of flame retarders in their composition - phosphorus and chlorine, which structure the epoxy polymer at elevated temperatures and increase the yield of carbonized structures, which, in turn, form a physical barrier to the interdiffusion of combustible gases and an oxidant in the combustion zone, reducing the flammability of the epoxy composite (Wenchao et al., 2014).

Basalt fibers produced by the Grafit R\&D establishment (Moscow), OAO Ivotsteklo (Ivot, Bryansk Region), OOO Kombinat Volna (Krasnoyarsk), and ZAO Belichsky Zavod Teplozvukoizolyatsiya (Irpin, Ukraine), as well as the UT900P (УТ-900П) carbon fabrics were used as reinforcing materials. Analyses of composite properties were carried out by standard methods.

\section{Results and discussion}

The efficiency of the oxidative method for increasing the activity of the carbon fiber surface was experimentally proved since the mechanical, physical-and-chemical, and chemical properties exceeded the similar characteristics of carbon fiber reinforced polymer samples based on the non-activated fiber (Table 1).

Table 1. Properties of the carbon fiber reinforced polymer based on the epoxy matrix reinforced with the untreated and activated carbon fiber.

\begin{tabular}{|l|l|l|l|l|l|l|}
\hline $\begin{array}{l}\text { Carbon } \\
\text { fiber } \\
\text { type }\end{array}$ & $\begin{array}{l}\text { Density, } \\
\mathrm{kg} / \mathrm{m}^{3}\end{array}$ & $\begin{array}{l}\text { Oxygen } \\
\text { index, } \\
\%\end{array}$ & $\begin{array}{l}\text { Water } \\
\text { absorp- } \\
\text { tion in } \\
\text { case of } \\
\text { boiling } \\
\text { within 2 } \\
\text { hours, } \\
\%\end{array}$ & $\begin{array}{l}\text { Break } \\
\text { point in } \\
\text { shear, } \\
\mathrm{MPa}\end{array}$ & $\begin{array}{l}\text { Break } \\
\text { point } \\
\text { under } \\
\text { bend- } \\
\text { ing, } \\
\mathrm{MPa}\end{array}$ & $\begin{array}{l}\text { Brinell } \\
\text { hard- } \\
\text { ness, } \\
\mathrm{MPa}\end{array}$ \\
\hline $\begin{array}{l}\text { Un- } \\
\text { treated }\end{array}$ & 1,350 & 62 & 0.55 & 14 & 600 & 596 \\
\hline $\begin{array}{l}\text { Activat- } \\
\text { ed }\end{array}$ & 1,428 & 66 & 0.41 & 14 & 645 & 627 \\
\hline
\end{tabular}

Basalt fibers modification by these methods affects the parameters of their porous structure. An increase in the maximum adsorbed volume and pore diameter for all types of basalt fiber modification, in comparison with untreated basalt fibers, is observed for fibers produced by the Grafit R\&D establishment (Moscow) and OAO Ivotsteklo (Ivot, Bryansk Region). At the same time, the used methods of modification do not cause significant changes in the structure of fibers produced by $\mathrm{OOO}$ Kombinat Volna (Krasnoyarsk) and ZAO Belichsky Zavod Teplozvukoizolyatsiya (Irpin, Ukraine).

These results are associated with differences of sizing agents applied to fibers. For example, the fibers of the Ukrainian and Krasnoyarsk manufacture were treated with the "active" sizing agent creating an oleophilic film on the surface, and the fibers produced by the Grafit 
R\&D establishment and OAO Ivotsteklo were treated with the "inert" sizing agent which gives the fiber surface oleophobic properties.

The presence of the oleophobic sizing agent on the surface of the BF causes a decrease in the physical-andchemical interaction between basalt fibers and monomers, which leads to an increase in water absorption and a decrease in physical and mechanical properties of basalt fiber reinforced polymers (Table 2 ).

The analysis of the obtained data shows that the physical-and-chemical as well as mechanical properties of basalt fiber reinforced polymers based on prepregs obtained by the method of polycondensation combination of components reinforced with modified basalt fibers produced by OAO Ivotsteklo exceed the similar indicators of basalt fiber reinforced polymers based on untreated fibers.

For example, for these basalt polymers reinforced with heat-treated and SHF-treated fibers, break point in shear, characterizing the adhesive interaction, increases. Brinell hardness increases by $15-20 \%$ with heat treatment and by $15 \%$ with SHF-treatment. Other indicators of basalt polymers reinforced with heat-treated fibers produced by the Grafit R\&D establishment (Brinell hardness, impact value, and break point under bending and in shear) increase as well.

The increase in physical-and-chemical as well as mechanical properties of the obtained basalt fiber reinforced polymers on the basis of modified fibers indicates a more active interaction between the functional groups of modified basalt fibers, produced by OAO Ivotsteklo and Grafit R\&D establishment, and phenolformaldehyde oligomer. This state is achieved by desizing and surface activation of fibers with the presented modification methods, thanks to which the number of functional groups available for interaction at the surface of basalt fibers increases (Table 2).

The use of different methods of surface activation allows providing high strength characteristics of carbon-, glass-, and basalt fiber reinforced polymers, exceeding similar characteristics of materials employed usually (Table 3).

Modification of the polymer matrix is equally important for the upgrade of the complex of properties. Previously

Table 2. Physical-and-chemical as well as mechanical properties of basalt fiber reinforced polymers based on basalt fibers of different manufacturers.

\begin{tabular}{|c|c|c|c|c|c|c|}
\hline Manufacturer & Modification & $\begin{array}{l}\text { Brinell hard- } \\
\text { ness, MPa }\end{array}$ & $\begin{array}{l}\text { Break point } \\
\text { under bending, } \\
\mathrm{MPa}\end{array}$ & $\begin{array}{l}\text { Break point in } \\
\text { shear, } \mathrm{MPa}\end{array}$ & $\begin{array}{l}\text { Impact value, } \\
\mathrm{kJ} / \mathrm{m}^{2}\end{array}$ & $\begin{array}{l}\text { Water absorp- } \\
\text { tion in case of } \\
\text { boiling within } 2 \\
\text { hours, } \%\end{array}$ \\
\hline \multirow{3}{*}{$\begin{array}{l}\text { Kombinat Volna } \\
\text { Ltd. }\end{array}$} & - & 503 & 600 & 14 & 329 & 0.26 \\
\hline & heat treatment & 500 & 605 & 14 & 330 & 0.26 \\
\hline & SHF-treatment & 500 & 600 & 14 & 320 & 0.25 \\
\hline \multirow[t]{3}{*}{ Ivotsteklo OJSC } & - & 510 & 640 & 20 & 342 & 0.24 \\
\hline & heat treatment & 614 & 683 & 27 & 385 & 0.23 \\
\hline & SHF-treatment & 586 & 654 & 26 & 360 & 0.23 \\
\hline \multirow{3}{*}{$\begin{array}{l}\text { Belichsky Zavod } \\
\text { Teplozvukoizoly- } \\
\text { atsiya CJSC }\end{array}$} & - & 475 & 450 & 29 & 313 & 0.24 \\
\hline & heat treatment & 470 & 453 & 18 & 315 & 0.25 \\
\hline & SHF-treatment & 470 & 448 & 18 & 313 & 0.25 \\
\hline \multirow{2}{*}{$\begin{array}{l}\text { Grafit R\&D } \\
\text { establishment }\end{array}$} & - & 233 & 422 & 12 & 190 & 0.33 \\
\hline & heat treatment & 338 & 518 & 16 & 210 & 0.28 \\
\hline
\end{tabular}

Table 3. Comparative characteristics of conventional structural and developed materials.

\begin{tabular}{|l|l|l|l|}
\hline Indicator & Steel & Aluminum alloy & $\begin{array}{l}\text { Glass basalt fiber reinforced } \\
\text { polymer }\end{array}$ \\
\hline Density, $\mathrm{kg} / \mathrm{m}^{3}$ & 7.8 & 2.7 & $1,8-1,9$ \\
\hline Elasticity modulus, $\mathrm{hPa}$ & 210 & 70 & 70 \\
\hline Strength limit, $\mathrm{MPa}$ & 390 & 250 & 1,700 \\
\hline $\begin{array}{l}\text { Temperature coefficient of } \\
\text { linear thermal expansion, } \mathrm{x} \\
10^{-6} \mathrm{\circ} \mathrm{C}\end{array}$ & $11.9-14.2$ & 2.4 & $0.45-8.3$ \\
\hline $\begin{array}{l}\text { Corrosion resistance: } \\
- \text { low } \\
- \text { high } \\
- \text { very high }\end{array}$ & $\mathrm{X}$ & $\mathrm{X}$ & $\mathrm{X}$ \\
\hline
\end{tabular}


Anton Mostovoy, Sergey Arzamastcev, Yulia Kadykova, Igor Danilov, Arthur Asoyan, Alexey Marusin — Pages 36-41 SURFACE ACTIVATION OF THE REINFORCING FILLER AND POLYMER MATRIX MODIFICATION AS EFFICIENT WAYS TO UPGRADE PROPERTIES OF POLYMER-MATRIX COMPOSITES BASED ON EPOXY MATRICES DOI: $10.23968 / 2500-0055-2018-3-4-36-41$

developed epoxy compositions were used as a polymer matrix in preparation of composites based on carbon fabrics.

UT-900P carbon fabrics (carbonized) in the amount from 20 to 50 pts. wt. were introduced in the epoxy composition containing (for 100 pts. wt. of ED-20) 30 pts. wt. of plasticizing agents (trichlorethyl phosphate (TCEP) and tricresyl phosphate (TCP)) and 40 pts. wt. of PO-300 hardening agent. Carbon fiber molding was carried out in two ways: fabrics proofing with the epoxy composition followed by hardening within 24 hours at the room temperature and heat treatment at $90^{\circ} \mathrm{C}$ and $150^{\circ} \mathrm{C}$ within 60 minutes (model samples) and compression molding at $150^{\circ} \mathrm{C}$ and the pressure of $25 \mathrm{MPa}$.

The epoxy resin hardened with $\mathrm{PO}-300$ is characterized by sufficiently high complex of properties (Table 4), in comparison with the epoxy resin hardened with PEPA; it is due to changes in density, the nature of spatial grid nodes

Table 4. Properties of epoxy composite model samples, plasticized with TCP.

\begin{tabular}{|c|c|c|c|c|c|}
\hline $\begin{array}{l}\text { Formulation of } \\
\text { the composition } \\
\text { hardened with } 40 \\
\text { pts. wt. of PO-300, } \\
\text { pts. wt. }\end{array}$ & $\begin{array}{l}\text { Break point under } \\
\text { bending, } \mathrm{MPa}\end{array}$ & Impact value, $\mathrm{kJ} / \mathrm{m}^{2}$ & $\begin{array}{l}\text { Brinell hardness, } \\
\mathrm{MPa}\end{array}$ & $\begin{array}{l}\text { Hardening degree, } \\
\%\end{array}$ & $\begin{array}{l}\text { Oxygen index, \% } \\
\text { vol. }\end{array}$ \\
\hline 100 ED-20 & 76 & 13 & 185 & 98 & 19 \\
\hline $\begin{array}{l}100 \text { ED-20 +50 } \\
\text { UT-900P }\end{array}$ & 162 & 51 & 292 & 85 & - \\
\hline 70 ED-20 + 30 TCP & $8^{*}$ & 36 & - & 84 & - \\
\hline $\begin{array}{l}100 \text { ED- } 20+30 \text { TCP } \\
+20 \text { UT-900P }\end{array}$ & 147 & 33 & 83 & 86 & 42 \\
\hline $\begin{array}{l}100 \text { ED- } 20+30 \text { TCP } \\
+30 \text { UT-900P }\end{array}$ & 140 & 51 & 98 & 86 & 42 \\
\hline $\begin{array}{l}100 \text { ED- } 20+30 \text { TCP } \\
+40 \text { UT-900P }\end{array}$ & 138 & 60 & 130 & 86 & 45 \\
\hline $\begin{array}{l}100 \text { ED- } 20+30 \\
T C P+50 \text { UT }\end{array}$ & 174 & 50 & 83 & 86 & 45 \\
\hline
\end{tabular}

${ }^{*}$ The coefficient of variation of properties $-5-10 \%$.

Table 5. Properties of epoxy composites plasticized with TCEP.

\begin{tabular}{|c|c|c|c|c|c|c|}
\hline $\begin{array}{l}\text { Sample } \\
\text { No. }\end{array}$ & $\begin{array}{l}\text { Formulation of the } \\
\text { composition hard- } \\
\text { ened with } 40 \text { pts. } \\
\text { wt. of PO-300 }\end{array}$ & $\begin{array}{l}\text { Break point under } \\
\text { bending, MPa }\end{array}$ & Impact value, $\mathrm{kJ} / \mathrm{m}^{2}$ & $\begin{array}{l}\text { Brinell hardness, } \\
\text { MPa }\end{array}$ & $\begin{array}{l}\text { Hardening de- } \\
\text { gree, } \%\end{array}$ & $\begin{array}{l}\text { Oxygen index, } \\
\% \text { vol. }\end{array}$ \\
\hline 1 & $\begin{array}{l}100 \text { ED-20 + } 30 \\
\text { TCEP }\end{array}$ & $4^{*}$ & 34 & Not determined & 84 & 30 \\
\hline 2 & $\begin{array}{l}100 \text { ED-20 + } 50 \\
\text { UT }\end{array}$ & 162 & 51 & 292 & 85 & - \\
\hline 3 & $\begin{array}{l}100 \text { ED-20+30 } \\
\text { TCEP + } 50 \text { UT- } \\
900 P\end{array}$ & $34^{*}$ & 162 & 110 & 86 & 60 \\
\hline 4 & $\begin{array}{l}100 \text { ED- } 20+30 \\
\text { TCEP + } 50 \text { UT- } \\
900 P\end{array}$ & $127^{*}$ & 91 & - & 90 & 50 \\
\hline 5 & $\begin{array}{l}100 \text { ED-20+30 } \\
\text { TCEP + } 50 \text { UT- } \\
900 P\end{array}$ & $85^{*}$ & 76 & 130 & 88 & 50 \\
\hline 6 & $\begin{array}{l}100 \text { ED- } 20+30 \\
\text { TCEP + } 50 \text { UT }\end{array}$ & $182^{*}$ & 162 & 83 & 88 & 60 \\
\hline
\end{tabular}

Note:

1. * samples do not destroy; deflection is equal to 1.5 of the sample thickness;

2. 3, 5, 6, 7-model samples;

4 - a molded sample;

3. the coefficient of variation of properties $-5-10 \%$. 
as a result of changes in the chemical composition of the epoxy polymer through the use of a hardening agent containing polyamide links chemically related to the grid structure.

The introduction of TCP plasticizing agent increases the resistance to impact, and samples do not destroy during bending tests (Table 4). In estimating the influence of the reinforcing filler on composite properties, it was found that the introduction of carbon fabrics in the unplasticized epoxy resin doubles the resistance to bending and increases the resistance to impact by four times (Table 4).

Upon an increase in the content of carbon fabrics in the plasticized composition from 20 to 50 pts. wt., stressstrain properties to the degree of filling of 40 pts. wt. do not change significantly (Table 4).

The replacement of TCP plasticizer by TCEP (Table 5 ), also introduced in the amount of 30 pts. wt., provides a substantial increase in physical and mechanical properties: the impact value increases from 50 to $162 \mathrm{~kJ} /$ $\mathrm{m}^{2}$, the samples do not destroy during bending tests at the bending stress value of $34 \mathrm{MPa}$.

Samples obtained by means of compression molding at the temperature of $150^{\circ} \mathrm{C}$ are characterized by higher hardening degree of $90 \%$ (Table 3 ), which leads to a decrease in the impact value from 162 to $91 \mathrm{MPa}$, while the bending stress increases from 34 to $127 \mathrm{MPa}$.

The use of unidirectional carbon fibers for reinforcement (sample 6 , Table 5 ) leads to a significant increase in the entire complex of mechanical properties, due to the possibility to realize stress-strain properties of the reinforcing filler to the limit. The developed carbon fiber reinforced polymers belong to the class of hardburning materials and exceed the industrial carbon fiber reinforced polymers with similar fillers in terms of the level of their properties.

\section{Conclusion}

The experiments proved that regardless of the basalt fiber manufacturer, desizing and surface activation lead to an increase in physical-and-chemical as well as mechanical properties of the obtained basalt fiber reinforced polymers, which indicates a more active interaction between the functional groups of modified basalt fibers and epoxy oligomer. It was proved that the replacement of tricresyl phosphate by trichlorethyl phosphate in the composition of the obtained carbon fiber reinforced polymer allows increasing the strength characteristics of the material, and the oxygen index significantly. 


\section{References}

Baloji Naik, R., Jagtap, S.B., Naik R.S., Malvankar, N.G., Ratna, D. (2014). Effect of non-ionic surfactants on thermomechanical properties ofepoxy. Multiwall carbon nanotubes composites, Progress in Organic Coatings, 77, pp. 1883-1889. DOI: 10.1016/j. porgcoat.2014.06.024.

Barile, C., Casavola, C., De Cillis, F. (2019). Mechanical comparison of new composite materials for aerospace applications. Composites Part B: Engineering, 162, pp. 122-128. DOI: 10.1016/j.compositesb.2018.10.101.

Colson, J. et al. (2018). Adhesion properties of regenerated lignocellulosic fibres towards poly(lactic acid) microspheres assessed by colloidal probe technique. Journal of Colloid and Interface Science, 532, pp. 819-829. DOI: 10.1016/j.jcis.2018.08.032.

EL-Wazery, M.S. (2018). Mechanical characterization of glass-basalt-carbon/polyester hybrid composites. International Journal of Engineering, Transactions A: Basics, 31 (7), pp. 1139-1145.

Gerasimova, V.M., Zubova, N.G., Ustinova, T.P. (2018). Effectiveness of Organosilane Modification of Basalt. Fibre Chemistry, 49 (6), pp. 357-359.

Matveeva, I.G., Lebedev, M.P. (2018). Polymer Composite Materials Based on Basalt. Theoretical Foundations of Chemical Engineering, 52 (4), pp. 670-672.

Molina, S. (2016). Modification of Natural Fibers Using Physical Technologies and Their Applications for Composites. Lignocellulosic Fibers and Wood Handbook: Renewable Materials for Today's Environment, pp. 323-344.

Singla, M., Chawla, V. (2010). Mechanical Properties of Epoxy Resin - Fly Ash Composite. Journal of Minerals \& Materials Characterization \& Engineering, 9 (3), pp. 199-210.

Tijana, S. et al. (2014). Improvement of epoxy resin properties by incorporation of $\mathrm{TiO}_{2}$ nanoparticles surface modified with gallic acid esters. Materials and Design, 62, pp. 158-167. DOI: 10.1016/j.matdes.2014.05.015.

Wenchao, Z. et al. (2014). The influence of the phosphorus-based flame retardant on the flame retardancy of the epoxy resins. Polymer Degradation and Stability, 109, pp. 209-217. DOI: 10.1016/j.polymdegradstab.2014.07.023. 